\title{
Saliva samples as a source of DNA for high throughput genotyping: an acceptable and sufficient means in improvement of risk estimation throughout mammographic diagnostics
}

\author{
U. G. Poehls ${ }^{1,2}$, C. C. Hack², A. B. Ekici ${ }^{3}$, M. W. Beckmann'², P. A. Fasching ${ }^{2}$, M. Ruebner ${ }^{2 *}$ and H. Huebner ${ }^{2}$
}

\begin{abstract}
Background: Breast cancer screening programs seem to be an insufficient tool for women at high genetic risk for breast cancer. These women are not adequately monitored yet. Genetic testing may improve clearly the quality of breast cancer prevention programs. At present, blood samples are favored for obtaining high-quality DNA; however, DNA can also be obtained by collecting saliva. The aim of this study was, on the one hand, to determine whether saliva sampling is a practicable means to obtain sufficient quantity and quality of DNA and, on the other hand, whether it is accepted by patients throughout mammographic diagnostics.
\end{abstract}

Methods: 67 consecutive women with diagnostic need for mammography with or without a family history for breast cancer were asked for their basic willingness to undergo a genetic testing by saliva sample in addition to standard diagnostics. Saliva samples were analyzed in terms of DNA quantity and quality.

Results: 64 (95.6\%) women agreed to provide a saliva sample; 3 of them denied participation. And even 63 out of 64 (98.4\%) were interested in their specific results. 45 out of 64 samples contained a DNA concentration above $50 \mathrm{ng} /$ $\mu \mathrm{l}, 12$ samples were between 25 and $50 \mathrm{ng} / \mu \mathrm{l}$ and only 7 of them were under $25 \mathrm{ng} / \mu \mathrm{l}$ with the standard extraction procedure.

Conclusion: A high number of patients seem to accept salvia samples as a risk assessment tool in breast diagnostics and are interested in their specific risk situation. At the same time, it could be demonstrated that it is an effective way to provide high-quality DNA for breast cancer gene analysis. However, it remains to be shown whether it would be possible to integrate it with the same acceptance in a nationwide breast cancer screening program.

Keywords: Breast cancer, Saliva, DNA extraction, DNA quality

\section{Background}

It is well known that breast cancer (BC) incidence increases worldwide. Global Burden of Disease Cancer Collaboration recently reported $\mathrm{BC}$ with a total number

\footnotetext{
*Correspondence: Matthias.ruebner@uk-erlangen.de

${ }^{2}$ Department of Gynecology and Obstetrics, University Breast Center Franconia, Comprehensive Cancer Center Erlangen-EMN, University Hospital Erlangen, Friedrich-Alexander University Erlangen-Nuremberg, Universitätsstrasse 21-23, 91054 Erlangen, Germany

Full list of author information is available at the end of the article
}

of 2,422,000 incident cases and 523,000 deaths in women (10,000 in men), making it the leading cause of cancer deaths for women in 2015 [1]. Overall, BC has the highest incidence rate in Germany and is the third leading cause of cancer related death. German national cancer report documents 71,640 incident cases, 17,853 deaths, and a 5 -year prevalence of 315,740 in 2013 [2].

Up to $25 \%$ of BC may be hereditary [3-5]. It is well known that $20 \%$ of hereditary $B C$ is caused by defects in the high penetrance genes BRCA1 [6], BRCA2 [7-9], and 
TP53 [10-13]. Several intermediate penetrance genes (CHEK2, ATM, PALB2, and RAD50) are responsible for about $5 \%$ of cases [14-21]. Nonetheless, BC heritability and tumor development based on a genetic defect seem to be more complex than originally expected. Since common lower-risk alleles, of which around 100 have been validated up to the present time through genome-wide association studies, replication and custom genotyping efforts, clarify around $25 \%$ of the risk $[4,5,22]$. Currently validated common genetic variations have been summarized in risk prediction models and offer a first possibility to assess the feasibility within early detection and screening programs [23]. Furthermore, first models have been developed to integrate mammographic density, which is an important risk factor for $\mathrm{BC}[24,25]$ and also influences sensitivity and specificity of mammography [26, 27], into risk prediction with genetic variants [28].

The knowledge about genetic $\mathrm{BC}$ risk factors will further increase soon. Therefore, the detection of individuals at risk should become much easier. National BC screening programs have not yet taken any genetic risk factors into account. Women at higher risk may be poorly protected due to too long screening intervals until following control and failure to examine by ultrasound and magnetic resonance imaging [29-33]. Women at low risk might receive an unjustified $x$-ray burden [34].

Genetic testing might offer a suitable way to maximize safety and minimize harm throughout $\mathrm{BC}$ screening and could potentially improve the program, and therefore individualize early detection and screening of BC. There is no effort to implement genetic testing in routine mammography so far. This may be due to too high cost or low patient acceptance.

To date, in genetic testing for risk assessment, blood tests are predominantly preferred. Not only the collection of samples is complex and the acceptance could be reduced due to painful blood collection, but there are concrete indications that non-invasive methods are preferred [35].

Sample acquisition using salivary leucocytes are available as an easy method to obtain germline DNA. This might be a chance of introducing genetic testing on a large scale within early detection and screening programs. In this study, we aimed at the analysis of DNA quality for these purposes as well as a first assessment on women's willingness to take part in genetic assessment for the purpose of individualized early detection and screening programs.

\section{Methods}

\section{Patients}

A total of 67 undergoing a diagnostic mammography necessitated by clinical findings or familial history were asked to participate in our recent study. Three out of 67 denied participation due to unknown reasons. Patients were asked to complete a questionnaire asking basic patient characteristics and their view on individualized early detection and screening of $\mathrm{BC}$ (see Additional file 1: Questionaire). Furthermore, they were asked to provide a saliva sample. All patients signed a written informed consent and the study was approved by the Ethics Committee of the Medical Faculty, Friedrich-Alexander University Erlangen Nuremberg (\#2100).

\section{Patient questionnaire}

Physical data (age, weight, height and menopausal status), obstetrical data (parity and age at first delivery), personal history per breast biopsy and family history per BC and ovarian cancer $(\mathrm{OC})$ were obtained by questionnaire survey (Additional file 1: Questionaire). All patient questionnaires were anonymized after completion.

\section{Sampling of saliva and DNA isolation}

Saliva from 64 women was collected using Oragene DNA (OG-500) all-in-one system (Genotek, Ottawa, Canada). All samples were completely anonymized. Saliva/OG-500 samples were stored up to 8 weeks at $4{ }^{\circ} \mathrm{C}$ until further processing.

For DNA isolation, two different protocols (manual and automated) were used and evaluated considering the complexity of the procedure, DNA yield and DNA quality. Prior to DNA isolation, saliva samples were incubated at $50{ }^{\circ} \mathrm{C}$ overnight with gentle agitation in an air incubator for adequate DNA release and permanent nuclease inactivation. The manual purification of DNA was performed using the prepIT L2P (PT-2LP, DNA genotek, Canada) reagent according to the manufacturer's instructions. In brief, $500 \mu \mathrm{l}$ of each sample was vortexed with $20 \mu \mathrm{l}$ of PT-L2P, incubated on ice for $10 \mathrm{~min}$ and centrifuged for $5 \mathrm{~min}$ at $15,000 \times g$. For DNA precipitation, $500 \mu \mathrm{l}$ of the supernatant was mixed with $600 \mu \mathrm{l}$ of 95\% EtOH. After 10-min incubation at room temperature, samples were centrifuged for $2 \mathrm{~min}$ at $15,000 \times g$. The DNA pellet was washed with $250 \mu \mathrm{l}$ of $70 \% \mathrm{EtOH}$. Finally, the pellet was dissolved in $80 \mu \mathrm{l}$ elution buffer. For the automated magnetic bead-based DNA purification, the saliva samples were processed on the Maxwell RSC instrument (Promega, Germany) using the Maxwell RSC Blood DNA Kit. For preprocessing of the samples, $300 \mu \mathrm{l}$ of saliva was incubated with $30 \mu$ l Proteinase K and $300 \mu \mathrm{l}$ lysis buffer for $20 \mathrm{~min}$ at $56^{\circ} \mathrm{C}$. The samples were then added to the cartridges according to the manufacturer's instructions and automatically processed. DNA was eluted in $80 \mu \mathrm{l}$ of Maxwell elution buffer. 


\section{Measurement of DNA concentration}

The concentration of isolated DNA was analyzed by two different methods. By using the Picodrop Microliter UV/ Vis Spectrophotometer, we assessed the concentration and purity of DNA in particular for protein contamination. Additionally, we used the Quantus Fluorometer (Promega, Germany) with the QuantiFluor dsDNA system for a specific quantification of dsDNA. Both measurements were performed according to the manufacturer's instructions.

\section{Assessment of DNA quality}

The quality of isolated DNA was analyzed by agarose gel electrophoresis [36]. Three microlitres of DNA was loaded onto a $2 \%$ agarose gel. Lambda DNA was used as a control as well as a marker for high-quality DNA. Nucleic acids were stained using peqGreen DNA/RNA dye (VWR, Germany). DNA quality was scored depending on molecular weight, grade of degradation, intensity of staining, and RNA contamination as detected by gel electrophoresis, with 1 high, 2 medium, and 3 low quality.

\section{PCR amplification of bacterial and human DNA}

To determine the ratio of human and bacterial DNA content, we performed a PCR amplification using primer sets specific for human beta-globin [37] or bacterial 16s rRNA. Oligonucleotides used for PCR amplification were beta-Globin_TF (sequence CAACTTCATCCACGTTCA CC), beta-Globin_BR (sequence GAAGAGCCAAGG ACAGGTAC), Ecoli_16s_TF (sequence CCTACGGGA GGCAGCAG), and Ecoli_16s_BR (sequence ATTACC GCGGCTGCTGG). The 16s rRNA gene is not present in human DNA but is conserved across a large range of microorganisms [38]. A total of $200 \mathrm{ng}$ isolated DNA was used per reaction. The regions of interest were amplified using the fast start taq DNA polymerase kit (SigmaAldrich) according to the manufacturer's instructions. To each sample, $0.5 \mu \mathrm{l}$ of DMSO was added to achieve specific primer binding. For both PCR reactions, an annealing temperature of $55^{\circ} \mathrm{C}$ was used. Finally, the amplified fragments were visualized by gel electrophoresis.

\section{Sequencing of BRCA1 and BRCA2}

All three mutations were confirmed in two independent DNAs of each patient. The identity of DNA pairs was confirmed by multiplex PCR with 21 polymorphic markers located on various chromosomes (PowerPlex21, Promega) [39] and analyzed on an automatic capillary sequencer (ABI3500, Applied Biosystems). Both small deletions were confirmed by Sanger sequencing analyzed on an automatic capillary sequencer (ABI3730, Applied Biosystems) as described by Kraus et al. [39]. The three exon deletion was confirmed by multiplex ligation-dependent probe amplification (MLPA) analysis [40] using the SALSA MLPA kit (BRCA1: P002; MRC Holland) according to the manufacturer's instructions.

\section{Results \\ Characteristics of participants}

A total of 65 out of 67 (97.0\%) women could be included into the study. Two women refused to take part. One 74-year-old woman was unable to provide a sample due to xerostomia (dry mouth). Mean age was $53.9 \pm 13.3$ years. $30(46.2 \%)$ of the respondents were in a premenopausal, $35(53.8 \%)$ in a postmenopausal status. The mean term starting menopause was $48.3 \pm 5.9$ years. 4 out of 64 (6.3\%) participants currently used hormonal replacement therapies. 8 out of $64(12.5 \%)$ women had a history of former breast biopsy, either core or surgical biopsy. 29 out of 65 (44.6\%) interviewed persons stated a family history of $\mathrm{BC}$ or $\mathrm{OC}$. The average number of affected family members was $1.3 \pm 0.6$, ranging $1-3.25$ women were from families in which only one female member had BC or OC. 5 women came from families with two affected members. None of the participants stated more than two affected family members. 8 women had affected mothers with $\mathrm{BC}$ or $\mathrm{OC}$. One woman indicated that her mother had both, BC and $\mathrm{OC}$, whereby no other family members were affected. All patient characteristics are described in Table 1.

With regard to our study aim concerning interest in genetic testing and counseling for individualized early detection or screening, 63 women (98.4\% of women who provided a sample, $96.9 \%$ of all participants) expressed an interest in genetic analysis and counseling. Only one person said she had no interest.

\section{Comparison DNA extraction methods}

In order to determine the quality and quantity of DNA from saliva samples, we isolated DNA from Oragene collection tubes (\#1 to 4) using two different methods (Maxwell/automated and prep-IT/manually). We assessed DNA quality by agarose gel electrophoresis. The DNA was of high molecular weight and of similar quantity regardless of the extraction method (Fig. 1). In contrast to that, we observed more signs of degrading and/or shearing of DNA from the prep-IT samples compared to DNA isolated with the Maxwell system (Fig. 1). Additionally, smear at the bottom of the lane indicated contamination of the prep-IT samples with degraded RNA (Fig. 1). Furthermore, purity of DNA was determined by photometric measurement of the absorbance at 260 and $230 \mathrm{~nm}$. In general, expected A260/A230 values are commonly within the range of 2.0-2.2. While we measured a ration above 2.0 for DNA isolated with the Maxwell system, prep-IT DNA exhibited signs of contamination with 
Table 1 Characteristics of participants

\begin{tabular}{|c|c|c|}
\hline Characteristics $(n=64)$ & Counts or mean & $\%$ or SD \\
\hline Age & 53.9 & \pm 13.3 \\
\hline Parity & 1.5 & \pm 1.1 \\
\hline Age at first delivery (years) & 25.8 & \pm 4.2 \\
\hline \multicolumn{3}{|l|}{ Menopausal status } \\
\hline Premenopausal & 30 & $46.2 \%$ \\
\hline Postmenopausal & 35 & $53.8 \%$ \\
\hline Age at menopause (years) & 48.3 & \pm 5.9 \\
\hline Duration since menopause (years) & 15.7 & \pm 9.1 \\
\hline \multicolumn{3}{|l|}{ HRT status } \\
\hline Recent hormonal replacement therapy & 4 & $6.2 \%$ \\
\hline No former hormonal replacement therapy & 61 & $93.8 \%$ \\
\hline \multicolumn{3}{|l|}{ Former breast biopsy } \\
\hline Yes & 8 & $12.3 \%$ \\
\hline No & 57 & $87.7 \%$ \\
\hline Women with at least one affected family member (BC or OC) & 29 & $44.6 \%$ \\
\hline Average number of affected family members & 1.3 & \pm 0.6 \\
\hline Women with mothers affected by $\mathrm{BC}$ or $\mathrm{OC}$ & 8 & $12.3 \%$ \\
\hline Women with mothers affected by $\mathrm{BC}$ and $\mathrm{OC}$ & 1 & $1.5 \%$ \\
\hline Women with one sister affected by BC & 4 & $6.2 \%$ \\
\hline Women with more than one sister affected by BC & 0 & $0 \%$ \\
\hline Women with affected grandmothers by BC & 10 & $15.4 \%$ \\
\hline Women with at least one other affected relative (e.g., aunts, cousins) by BC & 11 & $16.9 \%$ \\
\hline
\end{tabular}

Characteristics of all women, who participated in the study by giving saliva samples, are listed and quantified by counts (\%) or mean \pm standard deviation (SD)

carbohydrates as the ratio was less than 2.0 (Fig. 1). The amount of DNA differed only slightly between the two extraction methods, with a mean of $13.0 \mu \mathrm{g}$ total DNA per $300 \mu \mathrm{l}$ saliva in the Maxwell samples and 17.4 $\mu \mathrm{g}$ DNA per $500 \mu$ l saliva in the prep-IT ones (Fig. 1).

Contamination of saliva DNA with bacterial DNA is usual. Thus, we analyzed whether bacterial DNA was present after Maxwell- or prep-IT DNA extraction. We amplified human beta-Globin DNA and 16s ribosomal RNA (rRNA) from Escherichia coli by PCR and analyzed the amount by agarose gel electrophoresis. We did not observe any differences between the DNA samples regarding the content of beta-Globin and 16s rRNA (Fig. 1).

\section{DNA quality}

Since DNA isolated with the Maxwell system showed an overall better purity and quality with similar yield, we used this method to extract DNA from all 64 saliva samples. We determined the DNA quality of the 64 DNA probes using agarose gel electrophoresis. A tight band with a molecular weight similar to lambda DNA (48 kbp) could be visualized for all analyzed probes. Twenty-five samples showed a tight band with no detectable smearing representing highest DNA quality. For 25 additional DNA probes, we found minimal smearing within the higher molecular weight range. 14 of the 64 samples showed degraded DNA reaching to the bottom of the lane, but still with the largest proportion of DNA at a molecular weight of about $48 \mathrm{kbp}$ (Fig. 2).

\section{DNA concentration}

The DNA concentration was measured using the Quantus Fluorometer. We divided the DNA samples into three different groups depending on the DNA concentration requested for consortium-based genotyping or sequencing arrays e.g., OncoArray (required $>50 \mathrm{ng} / \mu \mathrm{l}$; in exceptional cases possible $25-50 \mathrm{ng} / \mu \mathrm{l}$; too low $<25 \mathrm{ng} / \mu \mathrm{l}) .7 \mathrm{of}$ 64 probes had concentrations of less than $25 \mathrm{ng} / \mu \mathrm{l}$, and 12 had a medium concentration between 25 and $50 \mathrm{ng} /$ $\mu \mathrm{l}$ (Fig. 3a). The largest proportion of DNA samples (70\%) had a concentration of more than $50 \mathrm{ng} / \mu \mathrm{l}$ (Fig. 3a). A total DNA amount above $5 \mu \mathrm{g}$ could be detected within $61 \%$ of all isolated DNA probes (Fig. $3 \mathrm{~b}$ ). The mean amount of DNA was $7.32 \mu \mathrm{g}$ per $300 \mu \mathrm{l}$ saliva.

\section{Detection of BRCA1 and BRCA2 mutations}

In order to compare DNA isolated from blood draws and DNA from saliva in regard to the detection of germline mutations, we sequenced blood and saliva DNA 


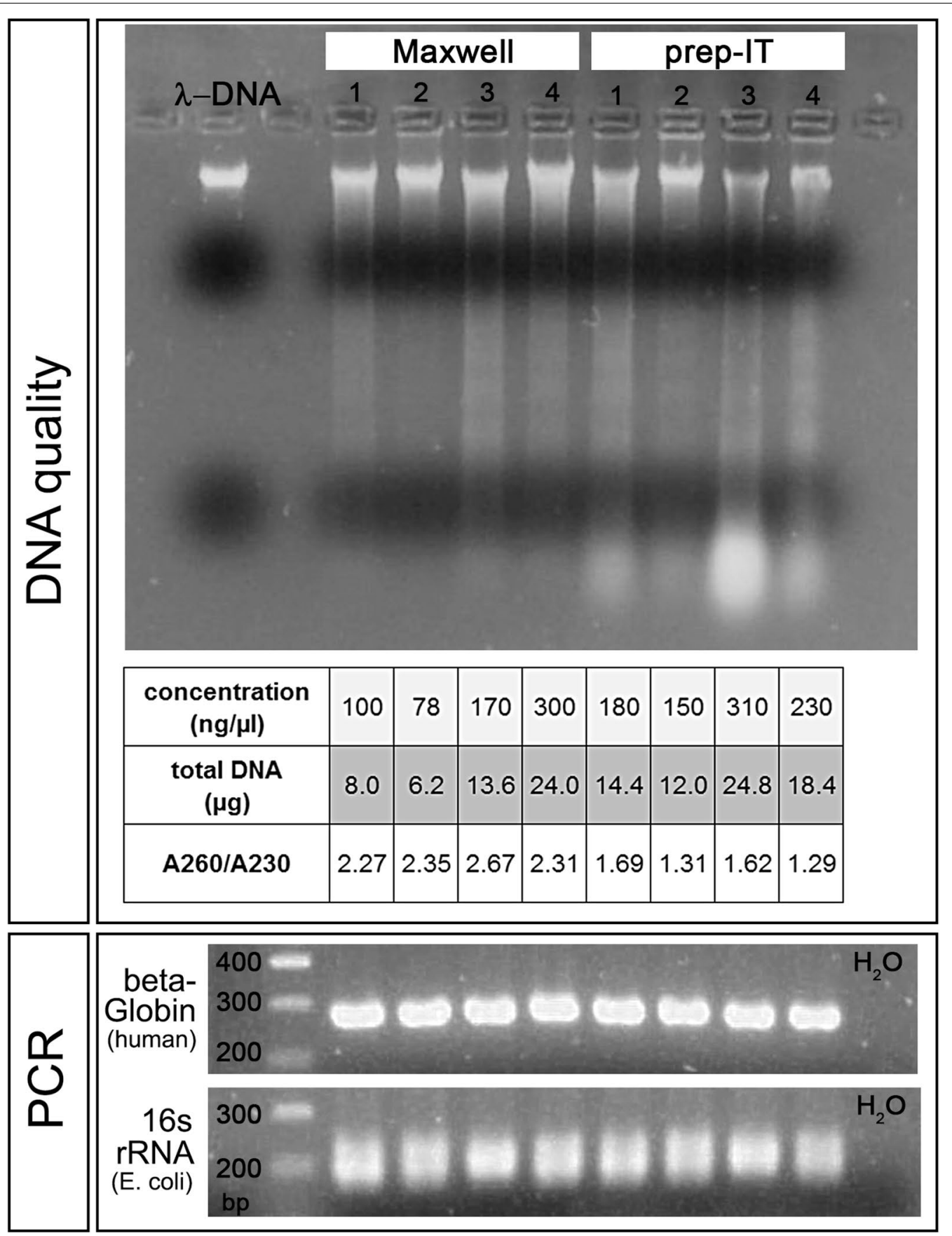

Fig. 1 Comparison of quality and bacterial contamination of DNA extracted using two different methods. DNA from four saliva samples (number 1-4) was isolated automatically (Maxwell) or manually (prep-IT). DNA quality was assessed by agarose gel electrophoresis. High-quality DNA is represented by a lambda DNA (300 ng) probe (first lane). DNA quantity was measured by fluorometric assessment (Quantus) and the purity of the DNA was quantified by photometric analysis of absorbance at 260 and $230 \mathrm{~nm}$ (A260/A230). PCR amplification of human beta-Globin DNA and bacterial 16s rRNA was used to determine differences in bacterial DNA contamination. In the first lane, a 100 base pairs (bp) DNA marker determines the size of the amplified fragments

from three different individuals with known mutations in the BRCA1 or BRCA2 loci. For all three individuals, we detected the identical BRCA1 and BRCA2 mutations in
DNA from saliva and from blood. Observed mutations, gene, and source of DNA are listed in Table 2. We further confirmed that DNA from blood draws and from saliva 


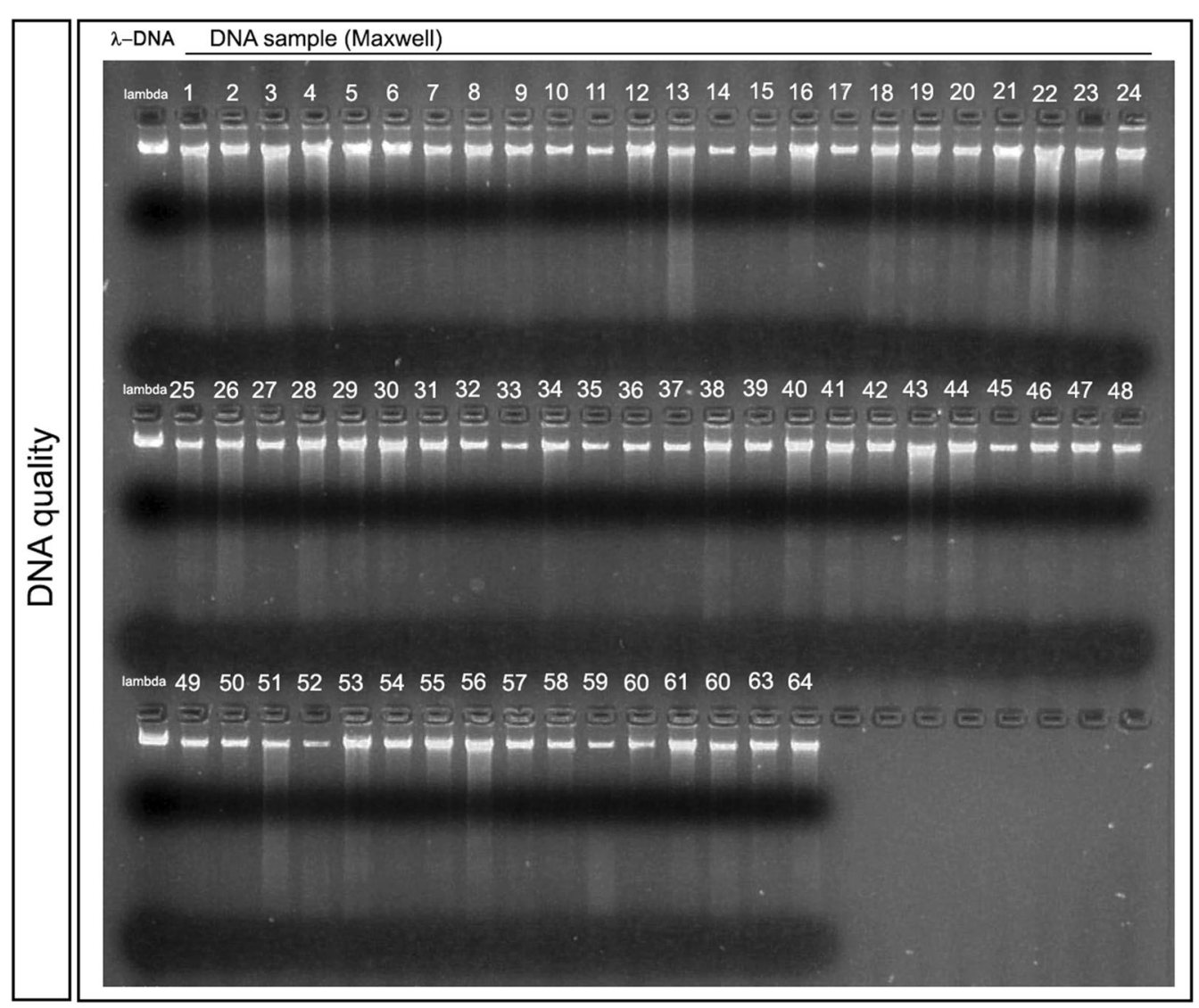

Fig. 2 DNA quality assessment by agarose gel electrophoresis. The quality of extracted DNA was analyzed by agarose gel electrophoresis. Three microlitres of each DNA sample (number 1-64) was loaded onto a 2\% agarose gel. The first lane shows lambda DNA (300 ng), which was used as a high-quality control, followed by the isolated DNA samples

collection belonged to the same individual by microsatellite analysis (data not shown).

\section{Discussion}

Nationwide Screening programs are established in 19 out of 28 European countries. Finland was the first to be started in 1989. The latest, however, were Spain, Latvia, Germany and Malta in 2009, and Denmark in 2010 [41]. Although most of the programs are population-based, up to now none of them are risk-based. Hence, nowadays national $\mathrm{BC}$ screening programs are non-personalized means in cancer detection and individual risks are not taken into any account. Nevertheless, percent mammographic breast density (PMD), structural features, familial history, and genetic variants are very well known as serious risk factors. Regarding the knowledge of several risk factors, there is a strong need for an individualized screening approach.

PMD is a well-known, strong risk factor with evidence of a genetic basis [42]. Ultimately, the entire number of genetic variants increasing $\mathrm{BC}$ risk is unclear. Hence, there is evidence suggesting that the presence of varying SNPs correlated with increased PMD and BC risk. Because there seems to be a strong connection between genetic characteristics and mammographic patterns, the question should be, whether an individualized BC detection approach should mention only density, genetic parameters or both. Lee et al. recently showed advantage of $\mathrm{BC}$ detection rate in a statistical model using both entities in an Asian population [43].

History of genetic testing in BC risk assessment goes back to the early 1990s [44]. Unfortunately, from that time until present, it is limited to a group of women with extended family history. Expanded BC screening is only offered to women with a lifetime risk above $20 \%$ based on estimates [23]. By extending and reinforcing of genetic testing beyond, e.g., BRCA $1 / 2$, the number of women who are candidates for extensive screening (like breast magnetic resonance imaging) could be significantly increased [45]. Most of those would not have been identified through family history assessment. On the other hand, there may be a part of population which 


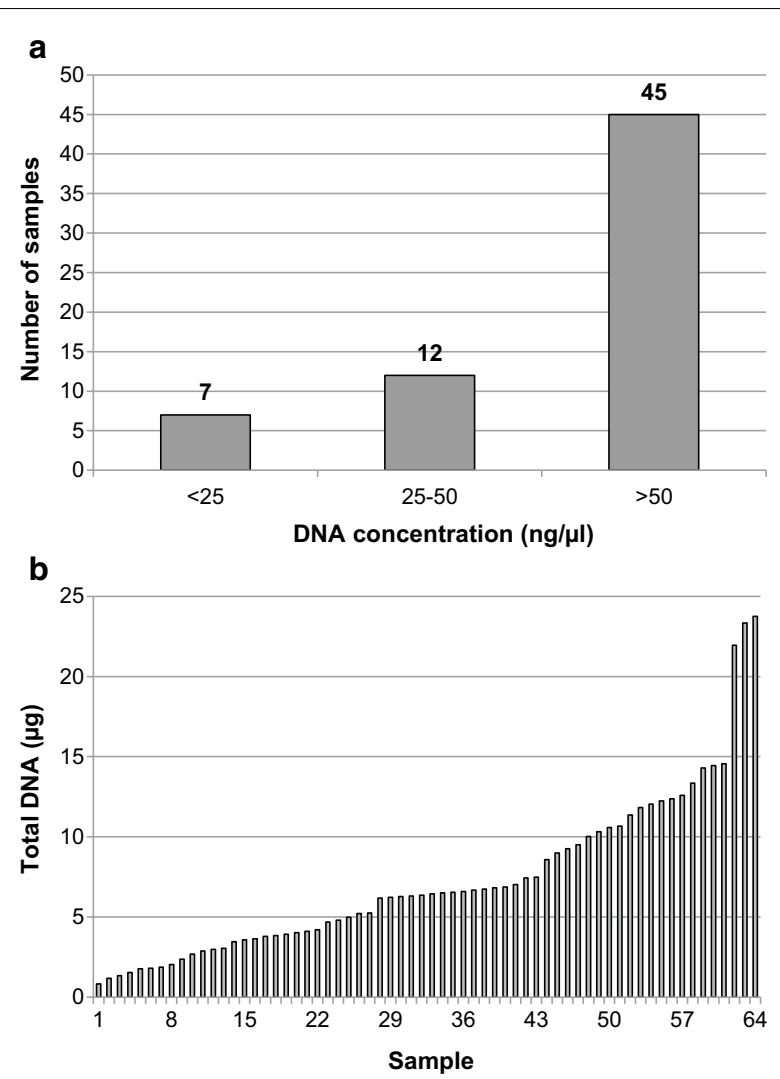

Fig. 3 Concentration of DNA. DNA concentrations of all 64 samples were determined by fluorometric measurement (Quantus). Samples were assembled into three groups of low (less than $25 \mathrm{ng} / \mu \mathrm{l}$ ), medium (between 25 and $50 \mathrm{ng} / \mu \mathrm{l}$ ), and high (more than $50 \mathrm{ng} / \mu \mathrm{l}$ ) DNA concentrations (a). The total DNA content of each sample was calculated and visualized in a waterfall diagram (b)

is over-protected by nationwide screening, because they are at extremely low risk. To detect these individuals and remove them from the screening program or modify the program by creating a low-risk group may decrease potential harm by unnecessary X-ray examinations.

Little scientific information exists about willingness of genetic testing in cancer. There are few data about readiness for genetic testing in prostatic cancer. For example,
$74 \%$ of prostatic cancer patients are probably or definitely interested in genetic analysis [46]. BC patients' willingness to accept genetic testing seems to be similarly and reaches $74.1 \%$ in a Chinese population [47]. Nevertheless, there are no data available about acceptance of genetic testing in a preventive setting. Results of a previous study [48] indicate that there is a correlation between knowledge about risk and willingness to join diagnostic or even therapeutic prevention programs. So, one way to achieve a high acceptance of genetic testing could be to facilitate a sufficient educational program. The other could be offering a special method of genetic testing with acceptance as high as possible amongst patients and screening participants, respectively.

In general, acceptance rates of genetic testing vary from 20 to $90 \%$ [49-51]. When analyzing the acceptance of genetic testing in subject to arising expenses, it was shown that there was a decreasing willingness with rising costs for patients [52-54]. Additionally, Adamkova et al. [35] showed a readiness for genetic testing in a group of healthy study volunteers depending on the sampling method used. The acceptance of blood sampling (72\%) and buccal swab sampling (98\%) differed considerable and consequently could be substantially improved by using the right method. These data are totally in line with our acceptance findings. We showed that in a routine early detection almost all women (98\%) are interested in learning more about individualized early detection including genetic testing.

Because buccal swab and, as we showed, saliva sampling are extremely high accepted methods of genetic testing in healthy women presented for early detection of $\mathrm{BC}$, we were interested whether quality and quantity of DNA from saliva samples could be adequate for testing of genetic risk factors. In that sense, we could extract a suitable quantity of DNA from saliva samples. The amount was comparable to other studies. For example, Looi et al. [55] extracted an average of $15 \mu \mathrm{g}$ DNA from $1.0 \mathrm{ml}$ saliva, while we observed a mean DNA yield of $7.3 \mu \mathrm{g}$ from $0.3 \mathrm{ml}$ saliva. When comparing two methods for isolation of DNA from saliva samples, we found that the automated, magnetic bead-based Maxwell RSC

Table 2 Sequencing of BRCA1 and BRCA2

\begin{tabular}{lll}
\hline Individual & Gene & Mutation \\
\hline 01 & BRCA1 & Deletion of Exons 1a, 1b and 2, IARC class 5. HGVS:C.(?_-200)_(80+1_81-1)del \\
01 & BRCA1 & Deletion of Exons 1a, 1b and 2, IARC class 5. HGVS:C.(?_-200)_(80+1_81-1)del \\
02 & BRCA2 & Exon 11:c.6379delA heterozygote; p.(Ser2127Valfs*10): IARC class 5 \\
02 & BRCA2 & Exon 11:c.6379delA heterozygote; p.(Ser2127Valfs*10): IARC class 5 \\
03 & BRCA1 & Exon 2: c.68_69delAG heterozygote, p./Glu23Valfs*17) (BIX: 18delAG); IARC class 5 (pathogen) \\
03 & BRCA1 & Exon 2: c.68_69delAG heterozygote, p./Glu23Valfs*17) (BIX: 18delAG); IARC class 5 (pathogen) \\
\hline
\end{tabular}


system was superior to manual purification with the prepIT L2P within our small test cohort. In particular, the purity of the isolated DNA was better using the Maxwell RSC system. Nevertheless, the bacterial content was identical and thus for both methods a specific quantification of human DNA (e.g., real-time PCR) would be necessary to determine the exact amount $[56,57]$. In earlier studies, it was shown that the mean number of bacterial cells per milliliter saliva is approximately $1.7 \times 10^{7}$, which represents about $90 \%$ of the total extracted DNA [58]. On the other hand, regardless of the amount of non-human DNA, it was shown that results obtained from further downstream studies, like sequencing or genotyping, were definite and accurate [56, 59]. Similar results could be obtained by us. Using Sanger sequencing or Multiplex ligation-dependent probe amplification, we detected identical mutations within BRCA1 and BRCA2 in DNA from blood and saliva. Taken together, we were able to show well suitable extraction methods for the isolation of DNA from saliva with high quality and quantity, a high interest in genetic testing when using saliva as a DNA source and a concordance between sequencing results of blood-based and saliva-based DNA. In summary, this makes saliva a well-suited source for a variety of studies and especially for the detection of cancer biomarkers (e.g., specific germline mutations in BRCA1 and BRCA2) during screening procedures [60].

\section{Conclusion}

Saliva sampling seems to be sufficient means for high throughput genotyping used for BC-risk stratification. In addition, it is accepted by patients in a diagnostic mammography setting due to its simple application. This might help to detect individuals at high risk who have need for intense surveillance. On the other side, it might be possible to detect women at low risk to avoid needless $\mathrm{x}$-ray exposure in the sense of longer screening intervals. Further investigation is needed to prove applicability in $\mathrm{BC}$ screening program.

\section{Additional file}

Additional file 1: Questionaire. Physical data (age, weight, height and menopausal status), obstetrical data (parity and age at first delivery), personal history per breast biopsy and family history per $\mathrm{BC}$ and ovarian cancer $(\mathrm{OC})$ were obtained by questionnaire survey

\section{Abbreviations}

BC: breast cancer; OC: ovarian cancer; bp: base pairs; rRNA: ribosomal RNA; PMD: percent mammographic breast density; TF: top forward; BR: bottom reverse; SNP: single-nucleotide polymorphism.

\section{Authors' contributions}

Conception and design: PAF, MR, HH, ABE; Collection of saliva samples: UGP; Patient questionnaire: UGP, CCH, HH; DNA extraction and analysis: $\mathrm{HH}, \mathrm{MR}$,
MWB; Interpretation of results: $\mathrm{HH}, \mathrm{MR}, \mathrm{UGP}, \mathrm{PAF}$; Drafting and revising the manuscript: UGP, HH, MR, PAF; Approval of the final version of the manuscript: UGP, HH, MR, PAF, MWB, CCH, ABE. All authors read and approved the final manuscript.

\section{Author details}

${ }^{1}$ Women's Health Center Wuerzburg, Kaiserstrasse 26, 97070 Würzburg, Germany. ${ }^{2}$ Department of Gynecology and Obstetrics, University Breast Center Franconia, Comprehensive Cancer Center Erlangen-EMN, University Hospital Erlangen, Friedrich-Alexander University Erlangen-Nuremberg, Universitätsstrasse 21-23, 91054 Erlangen, Germany. ${ }^{3}$ Institute of Human Genetics, Friedrich-Alexander-Universität Erlangen-Nürnberg (FAU), Schwabachanlage 10, 91054 Erlangen, Germany.

\section{Acknowledgements}

We thank Sonja Oeser for technical assistance.

\section{Competing interests}

The authors declare that they have no competing interests.

\section{Availability of data and materials}

All data generated or analyzed during this study are included in this published article.

\section{Ethics approval and consent to participate}

All patients signed a written informed consent and the study was approved by the Ethics Committee of the Medical Faculty, Friedrich-Alexander University Erlangen Nuremberg (\#2100). All investigations of people complied with national law and with the 1975 declaration of Helsinki in its current revised version. Informed consent was obtained from either participant of the study.

\section{Funding}

The present study was funded by the author's institutions.

\section{Publisher's Note}

Springer Nature remains neutral with regard to jurisdictional claims in published maps and institutional affiliations.

Received: 13 April 2017 Accepted: 10 April 2018

Published online: 27 April 2018

References

1. Global Burden of Disease Cancer C, Fitzmaurice C, Allen C, Barber RM, Barregard L, Bhutta ZA, Brenner H, Dicker DJ, Chimed-Orchir O, Dandona $R$, et al. Global, regional, and national cancer incidence, mortality, years of life lost, years lived with disability, and disability-adjusted life-years for 32 cancer groups, 1990 to 2015: a systematic analysis for the global burden of disease study. JAMA Oncol. 2016;3(4):524-48.

2. Barnes B, Kraywinkel K. Bericht zum Krebsgeschehen in Deutschland 2016. Zentrum für Krebsregisterdaten. 2017. https://www.krebsdaten .de/Krebs/DE/Content/Publikationen/Krebsgeschehen/Krebsgesch ehen_download.pdf?_blob=publicationFile

3. Kobayashi H, Ohno S, Sasaki Y, Matsuura M. Hereditary breast and ovarian cancer susceptibility genes (review). Oncol Rep. 2013;30:1019-29.

4. Michailidou K, Beesley J, Lindstrom S, Canisius S, Dennis J, Lush MJ, Maranian MJ, Bolla MK, Wang Q, Shah M, et al. Genome-wide association analysis of more than 120,000 individuals identifies 15 new susceptibility loci for breast cancer. Nat Genet. 2015;47:373-80.

5. Michailidou K, Hall P, Gonzalez-Neira A, Ghoussaini M, Dennis J, Milne RL, Schmidt MK, Chang-Claude J, Bojesen SE, Bolla MK, et al. Large-scale genotyping identifies 41 new loci associated with breast cancer risk. Nat Genet. 2013:45:353-61, 361e351-2.

6. Feunteun J. Breast cancer and genetic instability: the molecules behind the scenes. Mol Med Today. 1998;4:263-7.

7. Couch FJ, Farid LM, DeShano ML, Tavtigian SV, Calzone K, Campeau L, Peng Y, Bogden B, Chen Q, Neuhausen S, et al. BRCA2 germline mutations in male breast cancer cases and breast cancer families. Nat Genet. 1996;13:123-5. 
8. Wooster R, Bignell G, Lancaster J, Swift S, Seal S, Mangion J, Collins N, Gregory S, Gumbs C, Micklem G. Identification of the breast cancer susceptibility gene BRCA2. Nature. 1995;378:789-92.

9. Collins N, McManus R, Wooster R, Mangion J, Seal S, Lakhani SR, Ormiston W, Daly PA, Ford D, Easton DF, et al. Consistent loss of the wild type allele in breast cancers from a family linked to the BRCA2 gene on chromosome 13q12-13. Oncogene. 1995;10:1673-5.

10. Ara S, Lee PS, Hansen MF, Saya H. Codon 72 polymorphism of the TP53 gene. Nucleic Acids Res. 1990;18:4961

11. Cornelis RS, van Vliet M, Vos CB, Cleton-Jansen AM, van de Vijver MJ, Peterse JL, Khan PM, Borresen AL, Cornelisse CJ, Devilee P. Evidence for a gene on 17p13.3, distal to TP53, as a target for allele loss in breast tumors without p53 mutations. Cancer Res. 1994;54:4200-6.

12. Eyfjord JE, Thorlacius S, Valgardsdottir R, Gretarsdottir S, Steinarsdottir M, Anamthawat-Jonsson K. TP53 abnormalities and genetic instability in breast cancer. Acta Oncol. 1995;34:663-7.

13. Thorlacius S, Thorgilsson B, Bjornsson J, Tryggvadottir L, Borresen AL, Ogmundsdottir HM, Eyfjord JE. TP53 mutations and abnormal p53 protein staining in breast carcinomas related to prognosis. Eur J Cancer. 1995:31A:1856-61.

14. Meijers-Heijboer H, Wijnen J, Vasen $H$, Wasielewski M, Wagner A, Hollestelle A, Elstrodt F, van den Bos R, de Snoo A, Fat GT, et al. The CHEK2 $1100 \mathrm{del} C$ mutation identifies families with a hereditary breast and colorectal cancer phenotype. Am J Hum Genet. 2003;72:1308-14.

15. Schutte M, Seal S, Barfoot R, Meijers-Heijboer H, Wasielewski M, Evans DG, Eccles D, Meijers C, Lohman F, Klijn J, et al. Variants in CHEK2 other than 1100 delC do not make a major contribution to breast cancer susceptibility. Am J Hum Genet. 2003;72:1023-8.

16. Le Calvez-Kelm F, Lesueur F, Damiola F, Vallee M, Voegele C, Babikyan D, Durand G, Forey N, McKay-Chopin S, Robinot N, et al. Rare, evolutionarily unlikely missense substitutions in CHEK2 contribute to breast cancer susceptibility: results from a breast cancer family registry case-control mutation-screening study. Breast Cancer Res. 2011;13:R6.

17. Tavtigian SV, Oefner PJ, Babikyan D, Hartmann A, Healey S, Le Calvez-Kelm F, Lesueur F, Byrnes GB, Chuang SC, Forey N, et al. Rare, evolutionarily unlikely missense substitutions in ATM confer increased risk of breast cancer. Am J Hum Genet. 2009;85:427-46.

18. Walsh T, King MC. Ten genes for inherited breast cancer. Cancer Cell. 2007;11:103-5.

19. Hsu HM, Wang HC, Chen ST, Hsu GC, Shen CY, Yu JC. Breast cancer risk is associated with the genes encoding the DNA double-strand break repair Mre11/Rad50/Nbs1 complex. Cancer Epidemiol Biomark Prev. 2007;16:2024-32.

20. Tommiska J, Seal S, Renwick A, Barfoot R, Baskcomb L, Jayatilake H, Bartkova J, Tallila J, Kaare M, Tamminen A, et al. Evaluation of RAD50 in familial breast cancer predisposition. Int J Cancer. 2006;1 18:2911-6.

21. Heikkinen K, Karppinen SM, Soini Y, Makinen M, Winqvist R. Mutation screening of Mre11 complex genes: indication of RAD50 involvement in breast and ovarian cancer susceptibility. J Med Genet. 2003;40:e131.

22. Fasching PA, Ekici AB, Wachter DL, Hein A, Bayer CM, Haberle L, Loehberg CR, Schneider M, Jud SM, Heusinger K, et al. Breast cancer risk-from genetics to molecular understanding of pathogenesis. Geburtshilfe Frauenheilkd. 2013:73:1228-35.

23. Mavaddat N, Pharoah PD, Michailidou K, Tyrer J, Brook MN, Bolla MK, Wang $Q$, Dennis J, Dunning AM, Shah M. et al Prediction of breast cancer risk based on profiling with common genetic variants. J Natl Cancer Inst. 2015. https://doi.org/10.1093/jnci/djv036.

24. Heusinger K, Loehberg CR, Haeberle L, Jud SM, Klingsiek P, Hein A, Bayer CM, Rauh C, Uder M, Cavallaro A, et al. Mammographic density as a risk factor for breast cancer in a German case-control study. Eur J Cancer Prev. 2011;20:1-8.

25. Rauh C, Hack CC, Haberle L, Hein A, Engel A, Schrauder MG, Fasching PA Jud SM, Ekici AB, Loehberg CR, et al. Percent mammographic density and dense area as risk factors for breast cancer. Geburtshilfe Frauenheilkd. 2012;72:727-33.

26. Fasching PA, Heusinger $K$, Loehberg CR, Wenkel E, Lux MP, Schrauder M, Koscheck T, Bautz W, Schulz-Wendtland R, Beckmann MW, Bani MR. Influence of mammographic density on the diagnostic accuracy of tumor size assessment and association with breast cancer tumor characteristics. Eur J Radiol. 2006;60:398-404.
27. Haberle L, Fasching PA, Brehm B, Heusinger K, Jud SM, Loehberg CR, Hack CC, Preuss C, Lux MP, Hartmann A, et al. Mammographic density is the main correlate of tumors detected on ultrasound but not on mammography. Int J Cancer. 2016;139:1967-74.

28. Vachon CM, Pankratz VS, Scott CG, Haeberle L, Ziv E, Jensen MR, Brandt $\mathrm{KR}$, Whaley DH, Olson JE, Heusinger K, et al. The contributions of breast density and common genetic variation to breast cancer risk. J Natl Cancer Inst. 2015. https://doi.org/10.1093/jnci/dju397.

29. Kaas R, Muller SH, Hart AA, Rutgers EJ. Stage of breast cancers found during the surveillance of women with a familial or hereditary risk. Eur I Surg Oncol. 2008;34:501-7.

30. Warner E, Plewes DB, Shumak RS, Catzavelos GC, Di Prospero LS, Yaffe MJ, Goel V, Ramsay E, Chart PL, Cole DE, et al. Comparison of breast magnetic resonance imaging, mammography, and ultrasound for surveillance of women at high risk for hereditary breast cancer. J Clin Oncol. 2001;19:3524-31.

31. Warner E, Causer PA. MRI surveillance for hereditary breast-cancer risk. Lancet. 2005;365:1747-9.

32. Horsman D, Wilson BJ, Avard D, Meschino WS, Kim Sing C, Plante M, Eisen A, Howley HE, Simard J, National Hereditary Cancer Task Force. Clinical management recommendations for surveillance and risk-reduction strategies for hereditary breast and ovarian cancer among individuals carrying a deleterious BRCA1 or BRCA2 mutation. J Obstet Gynaecol Can. 2007:29:45-60.

33. Robson M. Breast cancer surveillance in women with hereditary risk due to BRCA1 or BRCA2 mutations. Clin Breast Cancer 2004;5:260-8; discussion 269-271.

34. Raftery J, Chorozoglou M. Possible net harms of breast cancer screening: updated modelling of Forrest report. BMJ. 2011;343:d7627.

35. Adamkova V, Veleminsky M, Zimmelova P, Hubacek JA. Volunteer's willingness to genetic testing - lack of the understanding of the matter. Physiol Res. 2009;58(Suppl 1):S53-4.

36. Zayats T, Young TL, Mackey DA, Malecaze F, Calvas P, Guggenheim JA. Quality of DNA extracted from mouthwashes. PLoS ONE. 2009;4:e6165.

37. Garcia-Closas M, Egan KM, Abruzzo J, Newcomb PA, Titus-Ernstoff L, Franklin T, Bender PK, Beck JC, Le Marchand L, Lum A, et al. Collection of genomic DNA from adults in epidemiological studies by buccal cytobrush and mouthwash. Cancer Epidemiol Biomark Prev. 2001;10:687-96.

38. Muyzer G, de Waal EC, Uitterlinden AG. Profiling of complex microbial populations by denaturing gradient gel electrophoresis analysis of polymerase chain reaction-amplified genes coding for 165 rRNA. Appl Environ Microbiol. 1993:59:695-700

39. Reuter MS, Riess A, Moog U, Briggs TA, Chandler KE, Rauch A, Stampfer M, Steindl K, Glaser D, Joset P, et al. FOXP2 variants in 14 individuals with developmental speech and language disorders broaden the mutational and clinical spectrum. J Med Genet. 2017;54:64-72.

40. Kraus C, Hoyer J, Vasileiou G, Wunderle M, Lux MP, Fasching PA, Krumbiegel M, Uebe S, Reuter M, Beckmann MW, Reis A. Gene panel sequencing in familial breast/ovarian cancer patients identifies multiple novel mutations also in genes others than BRCA1/2. Int J Cancer. 2017;140:95-102.

41. Altobelli E, Lattanzi A. Breast cancer in European Union: an update of screening programmes as of March 2014 (review). Int J Oncol. 2014:45:1785-92

42. Varghese JS, Thompson DJ, Michailidou K, Lindstrom S, Turnbull C, Brown J, Leyland J, Warren RM, Luben RN, Loos RJ, et al. Mammographic breast density and breast cancer: evidence of a shared genetic basis. Cancer Res. 2012;72:1478-84

43. Lee CP, Choi H, Soo KC, Tan MH, Chay WY, Chia KS, Liu J, Li J, Hartman M. Mammographic breast density and common genetic variants in breast cancer risk prediction. PLoS ONE. 2015;10:e136650.

44. Houlston RS, Lemoine L, McCarter E, Harrington S, MacDermot K, Hinton J, Berger L, Slack J. Screening and genetic counselling for relatives of patients with breast cancer in a family cancer clinic. J Med Genet. 1992:29:691-4.

45. Rosenthal ET, Evans B, Kidd J, Brown K, Gorringe H, van Orman M, Manley S. Increased identification of candidates for high-risk breast cancer screening through expanded genetic testing. J Am Coll Radiol. 2016:14:561-8.

46. Diefenbach MA, Schnoll RA, Miller SM, Brower L. Genetic testing for prostate cancer. Willingness and predictors of interest. Cancer Pract. 2000;8:82-6. 
47. Cheng X, Li Z, Sun X, Jiang B, Zhuang Z. Knowledge and willingness of breast cancer patients from Shanghai for genetic counseling and gene testing. Zhonghua Yi Xue Yi Chuan Xue Za Zhi. 2016;33:589-93.

48. Fasching PA, von Minckwitz G, Fischer T, Kaufmann M, Schultz-Zehden B, Beck H, Lux MP, Jacobs $V$, Meden $H$, Kiechle M, et al. The impact of breast cancer awareness and socioeconomic status on willingness to receive breast cancer prevention drugs. Breast Cancer Res Treat. 2007;101:95-104.

49. Sterling R, Henderson GE, Corbie-Smith G. Public willingness to participate in and public opinions about genetic variation research: a review of the literature. Am J Public Health. 2006;96:1971-8.

50. Stewart-Knox BJ, Bunting BP, Gilpin S, Parr HJ, Pinhao S, Strain JJ, de Almeida MD, Gibney M. Attitudes toward genetic testing and personalised nutrition in a representative sample of European consumers. $\mathrm{Br} \mathrm{J}$ Nutr. 2009;101:982-9.

51. Bhatti P, Sigurdson AJ, Wang SS, Chen J, Rothman N, Hartge P, Bergen AW, Landi MT. Genetic variation and willingness to participate in epidemiologic research: data from three studies. Cancer Epidemiol Biomark Prev. 2005;14:2449-53.

52. Bosompra K, Ashikaga T, Flynn BS, Worden JK, Solomon LJ. Psychosocial factors associated with the public's willingness to pay for genetic testing for cancer risk: a structural equations model. Health Educ Res. 2001;16:157-72

53. Matro JM, Ruth KJ, Wong YN, McCully KC, Rybak CM, Meropol NJ, Hall MJ. Cost sharing and hereditary cancer risk: predictors of willingness-to-pay for genetic testing. J Genet Couns. 2014;23:1002-11.
54. Ries NM, Hyde-Lay R, Caulfield T. Willingness to pay for genetic testing: a study of attitudes in a Canadian population. Public Health Genom. 2010;13:292-300

55. Looi M-L, Zakaria H, Osman J, Jamal R. Quantity and quality assessment of DNA extracted from saliva and blood. Clin Lab. 2012;58:307.

56. Quinque D, Kittler R, Kayser M, Stoneking M, Nasidze I. Evaluation of saliva as a source of human DNA for population and association studies. Anal Biochem. 2006;353:272-7.

57. Rylander-Rudqvist T, Hakansson N, Tybring G, Wolk A. Quality and quantity of saliva DNA obtained from the self-administrated oragene method-a pilot study on the cohort of Swedish men. Cancer Epidemiol Biomark Prev. 2006;15:1742-5.

58. Dawes $C$. Estimates, from salivary analyses, of the turnover time of the oral mucosal epithelium in humans and the number of bacteria in an edentulous mouth. Arch Oral Biol. 2003:48:329-36.

59. Bahlo M, Stankovich J, Danoy P, Hickey PF, Taylor BV, Browning SR, Brown MA, Rubio JP. Saliva-derived DNA performs well in large-scale, highdensity single-nucleotide polymorphism microarray studies. Cancer Epidemiol Biomark Prev. 2010;19:794-8.

60. Abraham JE, Maranian MJ, Spiteri I, Russell R, Ingle S, Luccarini C, Earl HM, Pharoah PP, Dunning AM, Caldas C. Saliva samples are a viable alternative to blood samples as a source of DNA for high throughput genotyping. BMC Med Genom. 2012;5:19.
Ready to submit your research? Choose BMC and benefit from:

- fast, convenient online submission

- thorough peer review by experienced researchers in your field

- rapid publication on acceptance

- support for research data, including large and complex data types

- gold Open Access which fosters wider collaboration and increased citations

- maximum visibility for your research: over $100 \mathrm{M}$ website views per year

At BMC, research is always in progress.

Learn more biomedcentral.com/submissions 